\title{
The Behavior of Some 2-Acetamido-2-deoxy-furanoses in the Presence of Alkaline Ion-exchange Resin
}

\author{
Hiroyuki Okumura, ${ }^{*}$ Makoto Kiso and Akira Hasegawa** \\ Department of Agricultural Chemistry, Gifu University, \\ Yanagido, Gifu 501-11, Japan \\ Received October 12, 1982
}

\begin{abstract}
In the presence of an alkaline ion-exchange resin (Amberlite IRA-410), 2-acetamido-2-deoxy5,6-O-isopropylidene-3-O-methyl- and -3-O-(tetrahydropyran-2-yl)-D-glucofuranoses, and 2acetamido-2-deoxy-5,6- $O$-isopropylidene-D-allofuranose, as well as 2-acetamido-2-deoxy-5,6- $O$ isopropylidene-D-glucofuranose were converted into 2-acetamido-2,3-dideoxy-5,6- $O$ isopropylidene- $\alpha$-D-erythro-hex-2-enofuranose. The $\beta$-elimination was also observed in the case of 2,5-diacetamido-2,5-dideoxy-D-xylo- and -D-ribo-furanoses, to give 2,5-diacetamido-2,3,5-trideoxyD-glycero-pent-2-enofuranose. C-3-Deoxy-furanoses, such as 2-acetamido-2,3-dideoxy-5,6-Oisopropylidene-D-arabino- and -D-ribo-hexofuranoses, and 2,3,5-triacetamido-2,3,5-trideoxy-Dribofuranose, however, did not give $\beta$-eliminated compounds under the same condition.
\end{abstract}

It is known that 2-acetamido-2-deoxy-Dglucose is converted into chromogens (unsaturated amino sugars) in an alkaline solution. The chemical structures of chromogens have been postulated by Kuhn et al. ${ }^{1)}$

Previously, we have reported ${ }^{2,5)}$ that reactions of 2-acetamido- or 2-(benzyloxycarbonylamino)-2-deoxy-D-glucoses with 2,2dimethoxy- or 2,2-dibenzyloxy-propane $-p$ toluenesulfonic acid - N,N-dimethylformamide yielded many kinds of isopropylidene derivatives as kinetically controlled products, e.g., methyl or benzyl 2-acetamido- or 2(benzyloxycarbonylamino)-2-deoxy-5,6- $O$ isopropylidene- $\beta$-D-glucofuranoside. These isopropylidene derivatives are effective to synthesize biologically active compounds. For example, Prumycin, ${ }^{4)}(+)$-biotin ${ }^{6)}$ and some analogs $^{7)}$ of $N$-acetylmuramoyl-L-alanyl-Disoglutamine were synthesized from benzyl 2-(benzyloxycarbonylamino)-2-deoxy-5,6-Oisopropylidene- $\beta$-D-glucofuranoside.

On the other hand, the treatment of 2 acetamido-2-deoxy-D-glucose with the reagents described above and subsequent removal of the acid with an alkaline ion- exchange resin (Amberlite IRA-410) afforded an unsaturated compound in addition to many kinds of isopropylidene derivatives. This compound was also obtained ${ }^{8)}$ from 2 -acetamido2-deoxy-5,6- $O$-isopropylidene-D-glucofuranose with the same resin. In the previous papers ${ }^{5,8)}$ we presumed the structure of the unsaturated compound to be 2-acetamido-1,4anhydro-2-deoxy-5,6-O-isopropylidene-Darabino-hex-1-enitol (2). Recently, Beau et al. have reported ${ }^{9)}$ that an alkaline treatment of 2 acetamido-2-deoxy-3,4:5,6-di- $O$-isopropylidene-aldehydo-D-glucose gave 2-acetamido2,3-dideoxy-5,6-O-isopropylidene- $\alpha$-Derythro-hex-2-enofuranose (1). Therefore, in this paper, we have reinvestigated the unsaturated compound described above and examined the behavior of some 2-acetamido2-deoxy-furanoses in the presence of alkaline ion-exchange resin.
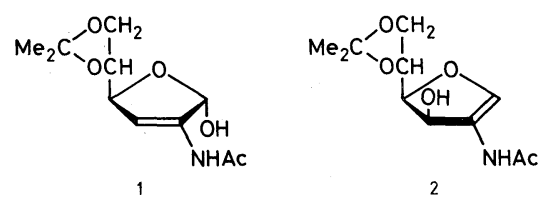

* Present address: Institute of Immunological Science, Hokkaido University, Sapporo 060, Japan.

** To whom inquiries should be addressed. 


\section{RESULTS AND DISCUSSION}

Previously, we have reported ${ }^{8)}$ that treatment of 2-acetamido-2-deoxy-5,6- $O$-isopropylidene-D-glucofuranose with Amberlite IRA-410 afforded an unsaturated compound as a crystalline material. Hydrogenation of this compound in methanol gave two derivatives $(\mathbf{3}, \mathbf{5})$, in the ratio of $1: 2$, after isolation by column chromatography. Both compounds reduced the Fehling solution. De- $O$-isopropylidenation of $\mathbf{3}$ and $\mathbf{5}$ by $60 \%$ acetic acid and subsequent acetylation at $0^{\circ} \mathrm{C}$ respectively gave 2 -acetamido-1,4,6-tri- $O$ acetyl-2,3-dideoxy- $\alpha$ - and - $\beta$-D-arabino-hexopyranoses (7a, 7b), and 2-acetamido-1,4,6-tri$O$-acetyl-2,3-dideoxy- $\alpha$-D-ribo-hexopyranose (8), which was identical with the acetylated Lividosamine. ${ }^{11)}$ These results indicate that compound $\mathbf{5}$ is 2-acetamido-2,3-dideoxy-5,6$O$-isopropylidene-D-ribo-hexofuranose, that 3 is 2-acetamido-2,3-dideoxy-5,6- $O$-isopropylidene-D-arabino-hexofuranose, and that the initial unsaturated compound is identical with 1 reported by Beau et al. Acetylation of 3 and 5 afforded 2-acetamido-1- $O$-acetyl-2,3dideoxy-5,6- $O$-isopropylidene- $\beta$-D-arabinohexofuranose $\left(4 ;[\alpha]_{\mathrm{D}}-94^{\circ}\right)$ and 2-acetamido-1- $O$-acetyl-2,3-dideoxy-5,6- $O$-isopropylidene- $\alpha$-D-ribo-hexofuranose $\left(6 ;[\alpha]_{\mathrm{D}}+\right.$ $\left.109^{\circ}\right)$ as the main products, respectively.

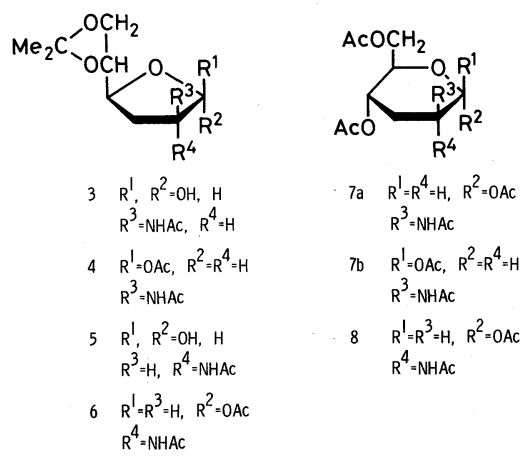

In order to examine behaviors of 2acetamido-2-deoxy-furanoses in the presence of an alkaline ion-exchange resin, we prepared 9 kinds of furanoses $(3,5,13 \sim 15,18$ and 22 24). The synthetic method for 2 -acet- amido-2-deoxy-5,6- $O$-isopropylidene-D-glucofuranose (13) has been described previously. ${ }^{5)} \quad 2$-Acetamido-2-deoxy-5,6- $O$-isopropylidene-3-O-methyl- and -3- $O$-(tetrahydropyran-2-yl)-D-glucofuranoses $(\mathbf{1 4}, \mathbf{1 5})$ were synthesized from benzyl 2-acetamido-2-deoxy-5,6- $O$-isopropylidene- $\beta$-D-glucofurano$\operatorname{side}^{3)}$ (9), via 3-O-methyl and 3-O-(tetrahydropyran-2-yl) compounds, respectively. For the preparation of 2-acetamido-2-deoxy5,6- $O$-isopropylidene-D-allofuranose compound 9. was first 3-O- methanesulfonylated with methanesulfonyl chloride to give compound 12, which was then converted by treatment with potassium acetate-aqueous $90 \%$ ethanol into benzyl 2-acetamido-2-deoxy5,6- $O$-isopropylidene- $\beta$-D-allofuranoside (16) in a high yield. The configuration of $\mathbf{1 6}$ was confirmed by ${ }^{1} \mathrm{H}-\mathrm{NMR}$ with the acetylated compound 17. The chemical shift of the H-3 proton $(\delta 5.47)$ and the coupling constant between $\mathrm{H}-2$ and $\mathrm{H}-3\left(J_{2,3}=6.0 \mathrm{~Hz}\right)$ were different from those of benzyl 2-acetamido-3$O$-acetyl-2-deoxy-5,6- $O$-isopropylidene- $\beta$-Dglucofuranoside $\left(\mathrm{H}-3 ; \delta 5.37, J_{2,3}=2.4 \mathrm{~Hz}\right)$. The results indicate that the configuration of 16 and $\mathbf{1 7}$ is a D-allo form. Hydrogenolitic
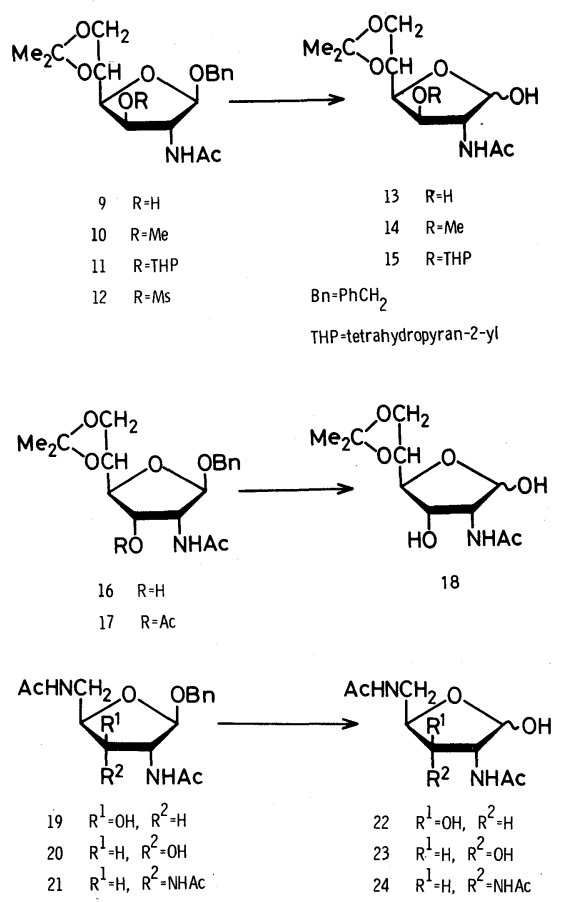
removal of the benzyl group in $\mathbf{1 6}$ gave the desired compound 18.

Recently, we have reported ${ }^{10)}$ that the hydrogenolysis of benzyl 2,5-diacetamido-2,5dideoxy- $\beta$-D-xylo- or - $\beta$-D-ribo-furanoside (19, 20) or benzyl 2,3,5-triacetamido-2,3,5-trideoxy- $\beta$-D-ribofuranoside (21) in a neutral condition, with subsequent acetylation afforded only the corresponding furanose derivatives. Therefore, in this study, we have used these 5-acetamido furanoses $(\mathbf{2 2} \sim \mathbf{2 4})$.

These furanoses $(3,5,13 \sim 15,18$ and $22 \sim 24)$ thus synthesized were each treated with Amberlite IRA-410 $\left(\mathrm{OH}^{-}\right)$resin in methanol. The 3-O-alkylated compounds (14, 15), as well as compound 13, were easily converted into 2 -enofuranose 1. The $\beta$-elimination was also observed in the case of the $\mathrm{D}$ allo isomer $\mathbf{1 8}$, to give compound $\mathbf{1}$. However, the C-3-unsubstituted compounds $(\mathbf{3}, 5)$ did not change under the same condition.
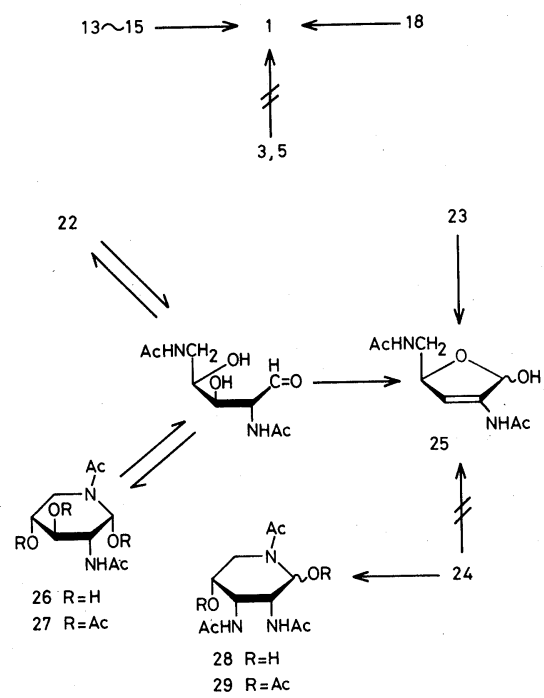

When compound 22 was treated with Amberlite IRA-410 ion-exchange resin in methanol at room temperature, 2,5-diacetamido-2,5-dideoxy-D-xylopyranose (26) was at first detected and the ratio of $\mathbf{2 6}$ to $\mathbf{2 2}$ reached $1: 1$ on TLC. Compound 26 was isolated from the reaction mixture as a crystalline product and then acetylated, to afford 2,5-diacetamido-1,3,4-tri- $O$-acetyl-2,5-dideoxy- $\alpha$-D-xylopyranose (27). The coupling constants of each proton in 27 at ${ }^{1} \mathrm{H}-\mathrm{NMR}$ $\left(J_{1,2}=3.8, \quad J_{2,3}=10.7, \quad J_{3,4}=9.1, \quad J_{4,5 \mathrm{a}}=10.2\right.$ and $\left.J_{4,5 \mathrm{e}}=5.7\right)$ indicate the compound is a $\alpha$-D-xylopyranose form. ${ }^{12,13)}$ On continuation of the reaction of 22 in an alkaline solution, 22 and 26 gradually disappeared and 2,5-di-acetamido-2,3,5-trideoxy-D-glyceropent-2-enofuranose (25) was produced. After chromatographic purification, compound 25 was isolated as crystals in a good yield. The ${ }^{1} \mathrm{H}-\mathrm{NMR}$ data of $\mathbf{2 5}$ are shown in Table I. The presence of two kinds of $\mathrm{NH}$ protons $(\delta 7.75 ; \mathrm{m}, \mathrm{NH}$ at $\mathrm{C}-5$ and $\delta 9.64 ; \mathrm{s}, \mathrm{NH}$ at $\mathrm{C}-2$ ) indicates that this compound is a furanoid form, and similar chemical shifts of $\mathrm{H}-1, \mathrm{H}-3$ and $\mathrm{H}-4$ to those of compound $\mathbf{1}$ show that the compound is a 2,3-unsaturated sugar. The anomeric configurations were determined from the observed $J_{1,4}$ values, as the coupling between $\mathrm{H}-1$ and $\mathrm{H}-4$ is large $(\sim 4 \mathrm{~Hz})$ when the proton is trans-related, and small $(\sim 1 \mathrm{~Hz})$ when the relationship is cis. ${ }^{14)}$ The data given in Table I are also comparable to those of the 3-deoxypent-enose derivatives reported by Ferrier and Hurford, ${ }^{15}$ and the anomeric ratio $(\alpha: \beta)$ in 25 was estimated at $\sim 1: 1$. When 26 was

TABLE I. ${ }^{1}$ H-NMR DATA ${ }^{a}$ FOR 2,3-UnSATURATEd Furanoses

\begin{tabular}{|c|c|c|c|c|c|c|c|}
\hline \multirow{2}{*}{ Compound $^{b}$} & \multicolumn{3}{|c|}{ Chemical shifts $(\delta)$} & \multicolumn{4}{|c|}{ Coupling constants $(\mathrm{Hz})$} \\
\hline & $\mathrm{H}-1$ & $\mathrm{H}-3$ & $\mathrm{H}-4$ & $J_{1,3}$ & $J_{1,4}$ & $J_{1, \mathrm{OH}}$ & $J_{3,4}$ \\
\hline $25(\alpha)$ & 5.71 & 5.99 & 4.75 & 0 & 4.3 & 8.0 & 1.0 \\
\hline $25(\beta)$ & 5.66 & 6.04 & 4.59 & 0 & 1.8 & 8.2 & 1.0 \\
\hline $1(\alpha)$ & 5.68 & 6.03 & 4.65 & 0 & 4.0 & 8.0 & 1.0 \\
\hline
\end{tabular}

a Measured at $90 \mathrm{MHz}$ in DMSO- $d_{6}$.

$b \quad \alpha$ or $\beta$ indicates a glycosidic linkage. 


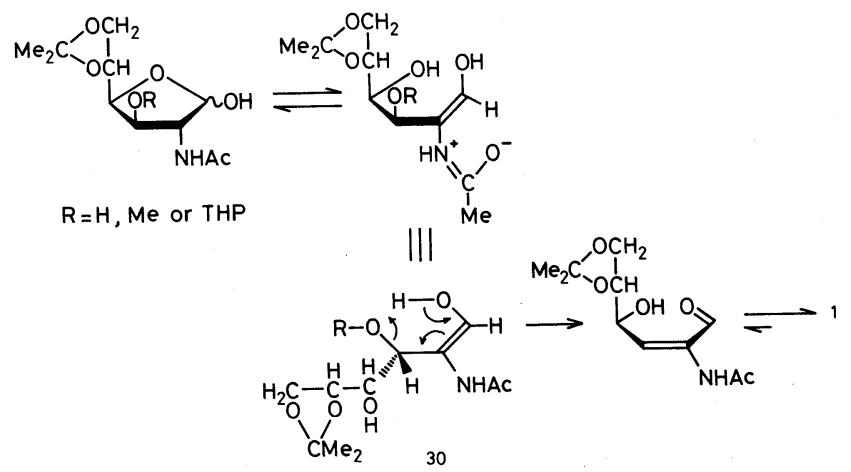

treated with Amberlite IRA-410 in methanol, the equilibrium between 26 and 22 was observed at first, and then only compound $\mathbf{2 5}$ was detected after the disappearance of both of 26 and 22 on TLC. Similarly, treatment of $\mathbf{2 3}$ with IRA-410 in methanol gave compound 25. In this case, a pyranose material corresponding to 26 was also detected on TLC at the initial stage of the reaction, although it was not isolated. On the other hand, the treatment of the triacetamido compound $\mathbf{2 4}$ in the same condition afforded 2,3,5-triacetamido-2,3,5trideoxy-D-ribopyranose (28) exclusively, and no unsaturated compound was detected. The ${ }^{1} \mathrm{H}-\mathrm{NMR}$ spectrum of the acetylated compound 29 revealed the presence of five acetyl groups (15 protons) at $\delta 1.97 \sim 2.12, \mathrm{H}-1$ of the $\alpha$-anomer as a doublet at $\delta 6.00(2.2 \mathrm{~Hz})$ and $\mathrm{H}-1$ of the $\beta$-anomer as a doublet at $\delta 6.16$ $(4.3 \mathrm{~Hz})$, and these data were consistent with a D-ribopyranose form. ${ }^{12)}$

As described above, when $\mathrm{OH}$ or $O$-alkyl groups are present at the $\mathrm{C}-3$ position, 2acetamido-2-deoxy-furanoses were converted into 2,3-unsaturated-furanose derivatives in the presence of an alkaline ion-exchange resin, and this conversion didn't occur in the case of 2-acetamido-2,3-dideoxy-furanose $(3,5)$ or 2,3,5-triacetamido-2,3,5-trideoxy-furanose (24). On the other hand, the configurational change at the $\mathrm{C}-3$ position such as compounds 18 and 23 didn't affect the $\beta$-elimination. These results indicate that the oxygen atom at the $C$ 3 position is required for this $\beta$-elimination. Formula 30 illustrates the mechanism proposed for the reaction. The existence of the enolic form, which is probably stabilized by the 2-acetamido group in the alkaline solution, is considered to be responsible for causing the $\beta$-elimination. In the case of the $2,5-$ diacetamido-furanoses $(22,23)$, although the furanose-pyranose equilibrium (22 26) was observed at the initial stage, the final product was the $\beta$-eliminated compound (in furanoid form). This result shows that the 2,3-unsaturated amino sugar is favorable for the furanoid structure.

\section{EXPERIMENTAL}

Melting points were determined with a Yanagimoto micro melting-point apparatus and are uncorrected. Specific rotations were determined with a Union PM-201 polarimeter and IR spectra were recorded with a Jasco IRA-1 spectrophotometer. NMR spectra were recorded at $60 \mathrm{MHz}$ and $90 \mathrm{MHz}$ with Hitachi R-24BS and R-22 spectrometers in $\mathrm{CDCl}_{3}$ and with TMS as an internal standard unless otherwise noted. Preparative chromatography was performed on silica gel (Wako Co.; 300 mesh) with the solvent systems specified. Evaporations were conducted in vacuo.

2-Acetamido-2,3-dideoxy-5,6-O-isopropylidene-Darabino-hexofuranose (3) and 2-acetamido-2,3-dideoxy5,6-O-isopropylidene-D-ribo-hexofuranose (5). A solution of 2-acetamido-2,3-dideoxy- $\alpha$-D-erythro-hex-2-enofuranose $^{8,9)}(1)(500 \mathrm{mg})$ in $\mathrm{MeOH}(30 \mathrm{ml})$ was kept for $24 \mathrm{hr}$ at room temperature, and the solution was then hydrogenated, with stirring, in the presence of $10 \%$ Pd-C catalyst $(250 \mathrm{mg})$ for $5 \mathrm{hr}$ at room temperature. After removal of the catalyst and evaporation of the solvent, the residue was chromatographed on a column of silica gel (40 g) with (a) $50: 1$, and (b) $20: 1 \mathrm{CHCl}_{3}-\mathrm{MeOH}$. The eluant (a) gave compound $3(150 \mathrm{mg}, 30 \%)$ as a syrup, $[\alpha]_{D}^{15}$ $-12^{\circ}(c=0.68, \mathrm{MeOH} ; 24 \mathrm{hr})$.

Eluant (b) afforded compound $5(310 \mathrm{mg}, 61 \%)$ as 
crystals, mp $142 \sim 143^{\circ} \mathrm{C},[\alpha]_{\mathrm{D}}^{23}+34.5^{\circ}(c=0.4$, DMSO; $24 \mathrm{hr}) ; v_{\max }^{\mathrm{Nu} j o l} \mathrm{~cm}^{-1}: 3330(\mathrm{OH}), 3230(\mathrm{NH}), 1610$ and 1570 (amide), and $840\left(\mathrm{Me}_{2} \mathrm{C}\right)$; NMR $\delta$ (90 MHz, DMSO- $\left.d_{6}\right)$ : 1.25 and $1.32\left(6 \mathrm{H}, 2 \mathrm{~s}, \mathrm{Me}_{2} \mathrm{C}\right), 1.79$ and $1.81(3 \mathrm{H}, 2 \mathrm{~s}, \mathrm{AcN})$, $1.60 \sim 2.15\left(2 \mathrm{H}, \mathrm{m}, \mathrm{H}-3,3^{\prime}\right), 4.79\left(\mathrm{~d}, J_{1,2}=0, J_{1, \mathrm{OH}}=4.8 \mathrm{~Hz}\right.$, $\mathrm{H}-1$ of $\beta$-anomer), $5.10\left(\mathrm{t}, J_{1,2}=J_{1, \mathrm{OH}}=4.5 \mathrm{~Hz}, \mathrm{H}-1\right.$ of $\alpha$ anomer), 6.26 (d, $J_{1, \mathrm{OH}}=4.8 \mathrm{~Hz}, \mathrm{OH}$ of $\beta$-anomer), 6.35 (d, $J_{1, \mathrm{OH}}=4.5 \mathrm{~Hz}, \mathrm{OH}$ of $\alpha$-anomer), $7.59\left(\mathrm{~d}, J_{2, \mathrm{NH}}=8.0 \mathrm{~Hz}\right.$; $\mathrm{NH}$ of $\alpha$-anomer) and $7.90\left(\mathrm{~d}, J_{2, \mathrm{NH}}=6.0 \mathrm{~Hz}, \mathrm{NH}\right.$ of $\beta$ anomer). Anal. Found: C, 53.77; H, 7.96; N, 5.69. Calcd. for $\mathrm{C}_{11} \mathrm{H}_{19} \mathrm{NO}_{5}: \mathrm{C}, 53.86 ; \mathrm{H}, 7.81 ; \mathrm{N}, 5.71 \%$

2-Acetamido-1-O-acetyl-2,3-dideoxy-5,6-O-isopropylidene- $\beta$-D-arabino-hexofuranose (4). Acetylation of 3 $(150 \mathrm{mg})$ with acetic anhydride $(1 \mathrm{ml})$ in pyridine $(3 \mathrm{ml})$ at $0^{\circ} \mathrm{C}$ gave the product. It was purified by chromatography on a column of silica gel $(15 \mathrm{~g})$ with $100: 1$ $\mathrm{CHCl}_{3}-\mathrm{MeOH}$, to give compound $4(120 \mathrm{mg}, 68 \%)$ as a syrup, $[\alpha]_{\mathrm{D}}^{22}-94^{\circ}\left(c=0.9, \mathrm{CHCl}_{3}\right) ; v_{\max }^{\mathrm{film}} \mathrm{cm}^{-1}: 3240(\mathrm{NH})$, $1740(\mathrm{C}=\mathrm{O}), 1650$ and 1540 (amide), and $840\left(\mathrm{Me}_{2} \mathrm{C}\right)$; NMR $\delta(90 \mathrm{MHz}): 1.33$ and $1.40\left(6 \mathrm{H}, 2 \mathrm{~s}, \mathrm{Me}_{2} \mathrm{C}\right), 1.98(3 \mathrm{H}$, s, AcN $), 2.10(3 \mathrm{H}, \mathrm{s}, \mathrm{AcO}), 1.60 \sim 1.97$ and $2.28 \sim 2.64$ $\left(2 \mathrm{H}, \mathrm{H}-3,3^{\prime}\right), 4.60\left(1 \mathrm{H}, \mathrm{m}, J_{1,2}=4.2, J_{2,3}=7.8, J_{2,3^{\prime}}=11.3\right.$, $\left.J_{2, \mathrm{NH}}=8.0 \mathrm{~Hz}, \mathrm{H}-2\right), 6.10\left(1 \mathrm{H}, \mathrm{d}, J_{1,2}=4.2 \mathrm{~Hz}, \mathrm{H}-1\right)$, and $6.29\left(1 \mathrm{H}, \mathrm{d}, J_{2, \mathrm{NH}}=8.0 \mathrm{~Hz}, \mathrm{NH}\right)$. Anal. Found: C, 54.55; $\mathrm{H}, 7.30 ; \mathrm{N}, 4.72$. Calcd. for $\mathrm{C}_{13} \mathrm{H}_{21} \mathrm{NO}_{6}$ : C, 54.34; $\mathrm{H}, 7.37$; $\mathrm{N}, 4.88 \%$.

2-Acetamido-1-O-acetyl-2,3-dideoxy-5,6-O-isopropylidene- $\alpha$-D-ribo-hexofuranose (6). Acetylation of 5 (150 $\mathrm{mg}$ ) was performed in the same way as described above. Recrystallization of the product from ether gave 6 (145 $\mathrm{mg}, 83 \%)$ as needles, $\mathrm{mp} 118^{\circ} \mathrm{C},[\alpha]_{\mathrm{D}}^{22}+109^{\circ}(c=0.4$, $\left.\mathrm{CHCl}_{3}\right) ; v_{\max }^{\text {Nujol }} \mathrm{cm}^{-1}: 3310(\mathrm{NH}), 1725(\mathrm{C}=\mathrm{O}), 1640$ and 1520 (amide), and $850\left(\mathrm{Me}_{2} \mathrm{C}\right)$; NMR $\delta$ (90 MHz): 1.33 and $1.43\left(6 \mathrm{H}, 2 \mathrm{~s}, \mathrm{Me}_{2} \mathrm{C}\right), 1.73 \sim 2.00(1 \mathrm{H}, \mathrm{m}, \mathrm{H}-3), 1.99$ $(3 \mathrm{H}, \mathrm{s}, \mathrm{AcN}), 2.10(3 \mathrm{H}, \mathrm{s}, \mathrm{AcO}), 2.41\left(1 \mathrm{H}, \mathrm{m}, J_{3,3^{\prime}}=12.5\right.$, $\left.J_{2,3^{\prime}}=8.3, J_{3^{\prime}, 4}=2.5 \mathrm{~Hz}, \mathrm{H}-3^{\prime}\right), 4.72\left(1 \mathrm{H}, \mathrm{m}, J_{1,2}=4.2\right.$, $\left.J_{2,3}=11.0, J_{2,3^{\prime}}=8.3, J_{2, \mathrm{NH}}=8.3 \mathrm{~Hz}, \mathrm{H}-2\right), 5.77(1 \mathrm{H}, \mathrm{d}$, $\left.J_{2, \mathrm{NH}}=8.3 \mathrm{~Hz}, \mathrm{NH}\right)$, and $6.15\left(1 \mathrm{H}, \mathrm{d}, J_{1,2}=4.2 \mathrm{~Hz}, \mathrm{H}-1\right)$. Anal. Found: C, 54.30; H, 7.42; N, 4.80. Calcd. for $\mathrm{C}_{13} \mathrm{H}_{21} \mathrm{NO}_{6}$ : C, 54.34; $\mathrm{H}, 7.37 ; \mathrm{N}, 4.88 \%$.

2-Acetamido-1,4,6-tri-O-acetyl-2,3-dideoxy- $\alpha$-Darabino-hexopyranose (7a) and 2-acetamido-1,4,6-tri-Oacetyl-2,3-dideoxy- $\beta$-D-arabino-hexopyranose (7b). A solution of $3(150 \mathrm{mg})$ in $60 \%$ aqueous acetic acid $(5 \mathrm{ml})$ was heated for $2 \mathrm{hr}$ at $45^{\circ} \mathrm{C}$, and evaporated. The syrupy residue was acetylated with acetic anhydride $(1 \mathrm{ml})$ in pyridine $(5 \mathrm{ml})$ at $0^{\circ} \mathrm{C}$. After evaporation, the residue was chromatographed on a column of silica gel $(15 \mathrm{~g})$ with $\mathrm{CHCl}_{3}$ and $70: 1 \mathrm{CHCl}_{3}-\mathrm{MeOH}$. With the latter eluate, compound 7a $(120 \mathrm{mg}, 59 \%)$ was obtained as the fastermoving component, $\mathrm{mp} 172^{\circ} \mathrm{C},[\alpha]_{\mathrm{D}}^{15}-36.7^{\circ}(c=0.65$, $\left.\mathrm{CHCl}_{3}\right) ; v_{\max }^{\mathrm{Nujol}} \mathrm{cm}^{-1}: 3290(\mathrm{NH}), 1740(\mathrm{C}=\mathrm{O})$, and 1640 and 1530 (amide); NMR $\delta$ (90 MHz): $2.01(3 \mathrm{H}, \mathrm{s}, \mathrm{AcN})$, 2.07 and $2.10(9 \mathrm{H}, 2 \mathrm{~s}, 3 \mathrm{AcO}), 5.82\left(1 \mathrm{H}, \mathrm{d}, J_{2, \mathrm{NH}}=8.0 \mathrm{~Hz}\right.$,
$\mathrm{NH})$, and $5.90\left(1 \mathrm{H}, \mathrm{d}, J_{1,2}=3.0 \mathrm{~Hz}, \mathrm{H}-1\right)$. Anal. Found: C, 50.86; $\mathrm{H}, 6.26 ; \mathrm{N}, 4.22$. Calcd. for $\mathrm{C}_{14} \mathrm{H}_{21} \mathrm{NO}_{8}$ : C, 50.75; $\mathrm{H}, 6.39 ; \mathrm{N}, 4.23 \%$.

Compound $\mathbf{7 b}$ appeared as the slower-moving component, and was obtained as a syrup $(35 \mathrm{mg}, 17 \%),[\alpha]_{\mathrm{D}}^{22}$ $-51^{\circ}\left(c=0.35, \mathrm{CHCl}_{3}\right) ; v_{\max }^{\text {film }} \mathrm{cm}^{-1}: 3250(\mathrm{NH}), 1740$ $(\mathrm{C}=\mathrm{O})$, and 1650 and 1540 (amide); NMR $\delta(90 \mathrm{MHz})$ $1.99,2.05,2.09$ and $2.13(12 \mathrm{H}, 4 \mathrm{~s}, \mathrm{AcN}$ and $3 \mathrm{AcO}), 5.05$ $\left(1 \mathrm{H}, \mathrm{m}, J_{3 \mathrm{a}, 4}=J_{4,5}=6.7, J_{3 \mathrm{e}, 4}=3.0 \mathrm{~Hz}, \mathrm{H}-4\right) 6.04(1 \mathrm{H}, \mathrm{d}$, $\left.J_{2, \mathrm{NH}}=8.0 \mathrm{~Hz}, \mathrm{NH}\right)$, and $6.13\left(1 \mathrm{H}, \mathrm{d}, J_{1,2}=4.3 \mathrm{~Hz}, \mathrm{H}-1\right)$. Anal. Found: C, 50.51; H, 6.44; N, 4.04. Calcd. for $\mathrm{C}_{14} \mathrm{H}_{21} \mathrm{NO}_{8}$ : C, 50.75; $\mathrm{H}, 6.39 ; \mathrm{N}, 4.23 \%$.

2-Acetamido-1,4,6-tri-O-acetyl-2,3-dideoxy- $\alpha$-D-ribohexopyranose $(\mathbf{8})$. Hydrolysis of $5(150 \mathrm{mg})$ and subsequent acetylation were carried out as described above. Crystallization of the product from ether gave compound $8\left(135 \mathrm{mg}, 67^{\circ}\right)$ as needles, $\mathrm{mp} 146 \sim 147^{\circ} \mathrm{C},[\alpha]_{\mathrm{D}}^{15}+108.5^{\circ}$ $\left(c=0.3, \mathrm{CHCl}_{3}\right) ;$ lit. $^{11)} \mathrm{mp} 151 \sim 152^{\circ} \mathrm{C},[\alpha]_{\mathrm{D}}^{23}+107.4^{\circ}(c=$ $0.5, \mathrm{CHCl}_{3}$ ).

Benzyl 2-acetamido-2-deoxy-5,6-O-isopropylidene-3-Omethyl- $\beta$-D-glucofuranoside (10). To a solution of benzyl 2 -acetamido-2-deoxy-5,6- $O$-isopropylidene- $\beta$-D-glucofuranoside $^{3)}$ (9) $(500 \mathrm{mg})$ in dry 1,4-dioxane $(5 \mathrm{ml})$ were added methyl iodide $(950 \mathrm{mg})$ and silver oxide $(1.6 \mathrm{~g})$. The mixture was stirred in the dark overnight at room temperature, and the insoluble materials were then removed by filtration. The filtrate was evaporated to a syrup which was chromatographed on a column of silica gel (20 g) with $\mathrm{CHCl}_{3}$ and 100:1 $\mathrm{CHCl}_{3}-\mathrm{MeOH}$. The latter eluate gave compound $10(510 \mathrm{mg}, 98 \%)$ as a syrup, $[\alpha]_{\mathrm{D}}^{26}$ $-98.1^{\circ}\left(c=0.7, \mathrm{CHCl}_{3}\right) ; v_{\max }^{\text {film }} \mathrm{cm}^{-1}: 3250(\mathrm{NH}), 1640$ and 1530 (amide), $850\left(\mathrm{Me}_{2} \mathrm{C}\right)$, and 740 and 690 (phenyl); NMR $\delta(60 \mathrm{MHz}): 1.30$ and $1.38\left(6 \mathrm{H}, 2 \mathrm{~s}, \mathrm{Me}_{2} \mathrm{C}\right), 1.88(3 \mathrm{H}$, $\mathrm{s}, \mathrm{AcN}), 3.47(3 \mathrm{H}, \mathrm{s}, \mathrm{MeO}), 5.00(1 \mathrm{H}, \mathrm{s}, \mathrm{H}-1), 6.52(1 \mathrm{H}$, broad s, NH), and $7.30(5 \mathrm{H}, \mathrm{s}, \mathrm{Ph})$. Anal. Found: C, 62.23; $\mathrm{H}, 7.37 ; \mathrm{N}, 3.70$. Calcd. for $\mathrm{C}_{19} \mathrm{H}_{27} \mathrm{NO}_{6}$ : C, 62.45; H, 7.45; $\mathrm{N}, 3.83 \%$.

Benzyl 2-acetamido-2-deoxy-5,6-O-isopropylidene-3-O(tetrahydropyran-2-yl)- $\beta$-D-glucofuranoside (11). To a solution of $9(400 \mathrm{mg})$ in dry 1,4-dioxane $(5 \mathrm{ml})$ were added dihydropyran $(200 \mathrm{mg})$ and $p$-toluenesulfonic acid monohydrate $(5 \mathrm{mg})$. The mixture was stirred for $4 \mathrm{hr}$ at room temperature, treated with Amberlite IR $-45\left(\mathrm{OH}^{-}\right)$resin to remove the acid, and evaporated to a syrup which was chromatographed on a column of silica gel $(20 \mathrm{~g})$, firstly with $\mathrm{CHCl}_{3}$, and then with $100: 1 \mathrm{CHCl}_{3}-\mathrm{MeOH}$. The latter eluant gave compound $11(480 \mathrm{mg}, 97 \%)$ as a syrup, $[\alpha]_{\mathrm{D}}^{26}-50.3^{\circ}\left(c=0.32, \mathrm{CHCl}_{3}\right) ; v_{\max }^{\mathrm{film}} \mathrm{cm}^{-1}: 3250(\mathrm{NH})$, 1640 and 1540 (amide), $840\left(\mathrm{Me}_{2} \mathrm{C}\right)$ and 740, 730, and 690 (phenyl). Anal. Found: C, 63.38; H, 7.71; N, 3.06. Calcd. for $\mathrm{C}_{23} \mathrm{H}_{33} \mathrm{NO}_{7}: \mathrm{C}, 63.43 ; \mathrm{H}, 7.64 ; \mathrm{N}, 3.22 \%$.

Benzyl 2-acetamido-2-deoxy-5,6-O-isopropylidene-3-Omesyl- $\beta$-D-glucofuranoside (12). To an ice-cooled solution 
of $9(1.0 \mathrm{~g})$ in dry pyridine $(10 \mathrm{ml})$ was added methanesulfonyl chloride $(500 \mathrm{mg}$ ), and the mixture was kept for $5 \mathrm{hr}$ at $0^{\circ} \mathrm{C}$. After evaporation of the solvent, the mixture was extracted with $\mathrm{CHCl}_{3}$, and the extract was successively washed with $2 \mathrm{M} \mathrm{HCl}, \mathrm{M} \mathrm{Na} \mathrm{Na}_{3}$ and $\mathrm{H}_{2} \mathrm{O}$, dried $\left(\mathrm{Na}_{2} \mathrm{SO}_{4}\right)$, and evaporated to a syrup. The product was purified by chromatography on a column of silica gel (25 g) with 100:1 $\mathrm{CHCl}_{3}-\mathrm{MeOH}$. Recrystallization from ether-hexane afforded $12(810 \mathrm{mg}, 66 \%)$ as needles, $\mathrm{mp}$ $110^{\circ} \mathrm{C},[\alpha]_{\mathrm{D}}^{18}-70.5^{\circ}\left(c=0.5, \mathrm{CHCl}_{3}\right) ; v_{\max }^{\mathrm{Nujol}} \mathrm{cm}^{-1}: 3240$ (NH), 1650 and 1545 (amide), 1340 and $1180\left(\mathrm{SO}_{2}\right), 840$ $\left(\mathrm{Me}_{2} \mathrm{C}\right)$, and 740 and 695 (phenyl); NMR $\delta$ (60 MHz): 1.31 and $1.42\left(6 \mathrm{H}, 2 \mathrm{~s}, \mathrm{Me}_{2} \mathrm{C}\right), 1.95(3 \mathrm{H}, \mathrm{s}, \mathrm{AcN}), 3.15(3 \mathrm{H}, \mathrm{s}$, $\left.\mathrm{MeSO}_{2}\right), 5.07 \sim 5.18(2 \mathrm{H}, \mathrm{H}-1$ and $\mathrm{H}-3), 6.60(1 \mathrm{H}$, broad s, $\mathrm{NH})$ and $7.34(5 \mathrm{H}, \mathrm{s}, \mathrm{Ph})$. Anal. Found: C, 53.30; H, 6.48; N, 3.23. Calcd. for $\mathrm{C}_{19} \mathrm{H}_{27} \mathrm{NO}_{8} \mathrm{~S}$ : C, 53.13; $\mathrm{H}, 6.34 ; \mathrm{N}$, $3.26 \%$.

2-Acetamido-2-deoxy-5,6-O-isopropylidene-3-O-meth$y l$-D-glucofuranose (14). To a solution of $\mathbf{1 0}(350 \mathrm{mg})$ in $\mathrm{MeOH}(15 \mathrm{ml})$ was added $10 \% \mathrm{Pd}-\mathrm{C}$ catalyst $(700 \mathrm{mg})$, and the mixture was hydrogenated, with stirring, for $3 \mathrm{hr}$ at $40^{\circ} \mathrm{C}$. The catalyst was filtered off and washed with $\mathrm{MeOH}$. The filtrate and washings were combined, and evaporated to a syrup which was chromatographed on a column of silica gel $(20 \mathrm{~g})$ firstly with $\mathrm{CHCl}_{3}$ and then 50:1 $\mathrm{CHCl}_{3}-\mathrm{MeOH}$. The latter eluate afforded compound $14(215 \mathrm{mg}, 82 \%)$ as crystals. Recrystallization from $\mathrm{EtOH}-\mathrm{Et}_{2} \mathrm{O}$ gave needles, mp $106 \sim 107^{\circ} \mathrm{C}$, $[\alpha]_{\mathrm{D}}^{26}-9.5^{\circ}(c=0.6, \mathrm{MeOH} ; 24 \mathrm{hr}) ; \mathrm{NMR} \delta(60 \mathrm{MHz})$ : 1.29 and $1.35\left(6 \mathrm{H}, 2 \mathrm{~s}, \mathrm{Me}_{2} \mathrm{C}\right), 2.00(3 \mathrm{H}, \mathrm{s}, \mathrm{AcN}), 5.20$ (d, $J_{1,2}=0, J_{1, \mathrm{OH}}=10.0 \mathrm{~Hz}, \mathrm{H}-1$ of $\beta$-anomer), 5.57 (dd, $J_{1,2}=5.5, J_{1, \mathrm{OH}}=4.0 \mathrm{~Hz}, \mathrm{H}-1$ of $\alpha$-anomer $), 5.78(1 \mathrm{H}$, $\mathrm{OH})$ and $6.60\left(1 \mathrm{H}, \mathrm{d}, J_{2, \mathrm{NH}}=7.0 \mathrm{~Hz}, \mathrm{NH}\right)$. Anal. Found: $\mathrm{C}, 52.41 ; \mathrm{H}, 7.80 ; \mathrm{N}, 4.98$. Calcd. for $\mathrm{C}_{12} \mathrm{H}_{21} \mathrm{NO}_{6}$ : C, 52.35; H, 7.69; N, 5.09\%.

2-Acetamido-2-deoxy-5,6-O-isopropylidene-3-O(tetrahydropyran-2-yl)-D-glucofuranose (15). To a solution of $11(220 \mathrm{mg})$ in $\mathrm{MeOH}(10 \mathrm{ml})$ was added $10 \% \mathrm{Pd}$ C catalyst $(400 \mathrm{mg}$ ), and the mixture was hydrogenated, with stirring, for $4 \mathrm{hr}$ at room temperature. After removal of the catalyst and evaporation of the solvent, the product was purified by chromatography on a column of silica gel (15 g) with 50:1 $\mathrm{CHCl}_{3}-\mathrm{MeOH}$ to give $15(121 \mathrm{mg}, 69 \%)$ as a syrup, $[\alpha]_{\mathrm{D}}^{28}+9.8^{\circ}\left(c=1.2, \mathrm{CHCl}_{3} ; 24 \mathrm{hr}\right) ; v_{\max }^{\mathrm{film}} \mathrm{cm}^{-1}$ : 3340-3260 (OH and NH), 1640 and 1520 (amide), and 840 $\left(\mathrm{Me}_{2} \mathrm{C}\right)$. Anal. Found: C, 55.35; H, 7.96; N, 3.99. Calcd. for $\mathrm{C}_{16} \mathrm{H}_{27} \mathrm{NO}_{7}: \mathrm{C}, 55.64 ; \mathrm{H}, 7.88 ; \mathrm{N}, 4.06 \%$.

Benzyl 2-acetamido-2-deoxy-5,6-O-isopropylidene- $\beta$-Dallofuranoside (16). To a solution of $12(780 \mathrm{mg})$ in $90 \%$ aqueous EtOH $(8 \mathrm{ml})$ was added AcOK $(500 \mathrm{mg})$, the mixture being boiled under reflux, with stirring, for $5 \mathrm{hr}$. After being cooled, the insoluble materials were removed by filtration and the filtrate was evaporated to a syrup which was chromatographed on a column of silica gel
(20 g) with $\mathrm{CHCl}_{3}$ and 100:1 $\mathrm{CHCl}_{3}-\mathrm{MeOH}$. The latter eluate afforded compound $16(630 \mathrm{mg})$ as a syrup which crystallized from ether-hexane to give plates $(570 \mathrm{mg}$, $89 \%), \mathrm{mp} 90^{\circ} \mathrm{C},[\alpha]_{\mathrm{D}}^{18}-42^{\circ}\left(c=0.6, \mathrm{CHCl}_{3}\right) ; v_{\max }^{\mathrm{Nujol}} \mathrm{cm}^{-1}$ : $3340(\mathrm{OH}), 3270(\mathrm{NH}), 1610$ and 1530 (amide), 850 $\left(\mathrm{Me}_{2} \mathrm{C}\right)$, and 750 and 695 (phenyl); NMR $\delta(60 \mathrm{MHz}): 1.31$ and $1.41\left(6 \mathrm{H}, 2 \mathrm{~s}, \mathrm{Me}_{2} \mathrm{C}\right), 1.98(3 \mathrm{H}, \mathrm{s}, \mathrm{AcN}), 5.06(1 \mathrm{H}, \mathrm{d}$, $\left.J_{1,2}=1.3 \mathrm{~Hz}, \mathrm{H}-1\right), 6.49\left(1 \mathrm{H}, \mathrm{d}, J_{2, \mathrm{NH}}=6.0 \mathrm{~Hz}, \mathrm{NH}\right)$, and $7.30(5 \mathrm{H}, \mathrm{s}, \mathrm{Ph})$. Anal. Found: C, 61.48; H, 7.14; N, 4.03 . Calcd. for $\mathrm{C}_{18} \mathrm{H}_{25} \mathrm{NO}_{6}: \mathrm{C}, 61.52 ; \mathrm{H}, 7.17 ; \mathrm{N}, 3.99 \%$.

Benzyl 2-acetamido-3-O-acetyl-2-deoxy-5,6-O-isopropylidene- $\beta$-D-allofuranoside (17). Acetylation of 16 (60 $\mathrm{mg})$ with acetic anhydride $(0.5 \mathrm{ml})$ in pyridine $(2 \mathrm{ml})$ at room temperature gave the product. Recrystallization from ether-hexane gave $17(60 \mathrm{mg}, 90 \%)$ as needles, $\mathrm{mp}$ $88.5 \sim 89^{\circ} \mathrm{C},[\alpha]_{\mathrm{D}}^{21}-66^{\circ}\left(c=0.5, \mathrm{CHCl}_{3}\right) ; v_{\max }^{\mathrm{Nujol}} \mathrm{cm}^{-1}: 3240$ (NH), 1750 and 1230 (ester), 1650 and 1540 (amide), 840 $\left(\mathrm{Me}_{2} \mathrm{C}\right)$, and 740 and 695 (phenyl); NMR $\delta(60 \mathrm{MHz}): 1.30$ and $1.40\left(6 \mathrm{H}, 2 \mathrm{~s}, \mathrm{Me}_{2} \mathrm{C}\right), 1.95(3 \mathrm{H}, \mathrm{s}, \mathrm{AcN}), 2.02(3 \mathrm{H}, \mathrm{s}$, AcO), 4.00 (1H, m, H-4), $4.26(1 \mathrm{H}, \mathrm{m}, \mathrm{H}-2), 5.03(1 \mathrm{H}, \mathrm{d}$, $\left.J_{1,2}=2.3 \mathrm{~Hz}, \mathrm{H}-1\right), 5.47\left(1 \mathrm{H}, \mathrm{t}, J_{2,3}=J_{3,4}=6.0 \mathrm{~Hz}, \mathrm{H}-3\right)$, $6.67\left(1 \mathrm{H}, \mathrm{d}, J_{2, \mathrm{NH}}=7.0 \mathrm{~Hz}, \mathrm{NH}\right)$, and $7.28(5 \mathrm{H}, \mathrm{s}, \mathrm{Ph})$. Anal. Found: C, 61.27; H, 6.80; N, 3.51. Calcd. for $\mathrm{C}_{20} \mathrm{H}_{27} \mathrm{NO}_{7}$ : C, 61.05; H, 6.92; N, 3.56\%.

2-Acetamido-2-deoxy-5,6-O-isopropylidene-D-allofuranose (18). To a solution of $16(350 \mathrm{mg})$ in $\mathrm{MeOH}(25$ $\mathrm{ml}$ ) was added $10 \% \mathrm{Pd}-\mathrm{C}$ catalyst $(400 \mathrm{mg})$, the mixture being hydrogenated, with stirring, for $5 \mathrm{hr}$ at $30^{\circ} \mathrm{C}$. After removal of the catalyst and evaporation of the solvent, the product was purified by chromatography on a column of silica gel $(15 \mathrm{~g})$ with $50: 1$ and then $20: 1$ $\mathrm{CHCl}_{3}-\mathrm{MeOH}$. The latter eluate gave compound 18 $(211 \mathrm{mg}, 81 \%)$ as crystals. Recrystallization from EtOH$\mathrm{Et}_{2} \mathrm{O}$ gave needles, $\mathrm{mp} 133 \sim 134^{\circ} \mathrm{C},[\alpha]_{\mathrm{D}}^{20}-10^{\circ}(c=0.5$, MeOH; $24 \mathrm{hr}) ; v_{\max }^{\mathrm{Nujol}} \mathrm{cm}^{-1}: 3400(\mathrm{OH}), 3240(\mathrm{NH}), 1610$ and 1540 (amide), and $840\left(\mathrm{Me}_{2} \mathrm{C}\right)$. Anal. Found: C, 50.68; $\mathrm{H}, 7.46 ; \mathrm{N}, 5.29$. Calcd. for $\mathrm{C}_{11} \mathrm{H}_{19} \mathrm{NO}_{6}$ : C, 50.56; $\mathrm{H}, 7.33$; $\mathrm{N}, 5.36 \%$.

2,5-Diacetamido-2,5-dideoxy-D-xylofuranose (22). To a solution of benzyl 2,5-diacetamido- 2,5-dideoxy- $\beta$-D- xylofuranoside $^{10)}(19)(1.1 \mathrm{~g})$ in $60 \%$ aqueous $\mathrm{MeOH}(70 \mathrm{ml})$ and $\mathrm{AcOH}(0.7 \mathrm{ml})$ was added $10 \% \mathrm{Pd}-\mathrm{C}$ catalyst $(300 \mathrm{mg})$. The mixture was hydrogenated, with stirring, for $3 \mathrm{hr}$ at room temperature. The catalyst was removed by filtration, and the filtrate was evaporated to give crystals which recrystallized from EtOH-Et ${ }_{2} \mathrm{O}$. Compound 22 was obtained as needles, yield $610 \mathrm{mg}(77 \%), \mathrm{mp} 171^{\circ} \mathrm{C},[\alpha]_{\mathrm{D}}^{26}$ $+64^{\circ}(c=0.5, \mathrm{MeOH} ; 24 \mathrm{hr}) ; v_{\max }^{\mathrm{Nujol}} \mathrm{cm}^{-1}: 3410 \sim 3260$ (OH and $\mathrm{NH}$ ), 1635, 1620 and 1560 (amide). Anal. Found: C, 46.41; $\mathrm{H}, 6.89 ; \mathrm{N}, 11.75$. Calcd. for $\mathrm{C}_{9} \mathrm{H}_{16} \mathrm{~N}_{2} \mathrm{O}_{5}$ : C, $46.54 ; \mathrm{H}, 6.94 ; \mathrm{N}, 12.06 \%$.

2,5-Diacetamido-2,5-dideoxy-D-ribofuranose (23) To a solution of benzyl 2,5-diacetamido-2,5-dideoxy- $\beta$-D- 
ribofuranoside ${ }^{10)}(20)(480 \mathrm{mg})$ in $80 \%$ aqueous $\mathrm{MeOH}$ $(15 \mathrm{ml})$ and $\mathrm{AcOH}(0.15 \mathrm{ml})$ was added $10 \% \mathrm{Pd}-\mathrm{C}$ catalyst $(500 \mathrm{mg})$, and the mixture was hydrogenated for $3.5 \mathrm{hr}$ at room temperature. After the same treatment as described above, compound $23(245 \mathrm{mg}, 71 \%)$ was obtained as needles, $\mathrm{mp} 151 \sim 153^{\circ} \mathrm{C},[\alpha]_{\mathrm{D}}^{20}-16^{\circ} \quad(c=0.5, \mathrm{MeOH}$; $24 \mathrm{hr}) ; v_{\max }^{\mathrm{Nujol}} \mathrm{cm}^{-1}: 3380,3340,3290$ and $3260(\mathrm{OH}, \mathrm{NH})$, and 1640, 1610, 1560 and 1540 (amide); NMR $\delta(60 \mathrm{MHz}$, $\left.\mathrm{CD}_{3} \mathrm{OD}\right): 1.93,1.99$ and $2.01(6 \mathrm{H}, 3 \mathrm{~s}, 2 \mathrm{AcN}), 5.13(\mathrm{~d}$, $J_{1,2}=2.1 \mathrm{~Hz}, \mathrm{H}-1$ of $\beta$-anomer), and $5.30\left(\mathrm{~d}, J_{1,2}=4.3 \mathrm{~Hz}\right.$, $\mathrm{H}-1$ of $\alpha$-anomer). Anal. Found: C, 46.18; H, 6.80; N, 11.81. Calcd. for $\mathrm{C}_{9} \mathrm{H}_{16} \mathrm{~N}_{2} \mathrm{O}_{5}: \mathrm{C}, 46.54 ; \mathrm{H}, 6.94 ; \mathrm{N}$, $12.06 \%$.

2,3,5-Triacetamido-2,3,5-trideoxy-D-ribofuranose (24). To a solution of benzyl 2,3,5-triacetamido-2,3,5-trideoxyl$\beta$-D-ribofuranoside ${ }^{10)}(21)(520 \mathrm{mg})$ in $70 \%$ aqueous $\mathrm{MeOH}(30 \mathrm{ml})$ and $\mathrm{AcOH}(0.3 \mathrm{ml})$ was added $10 \% \mathrm{Pd}-\mathrm{C}$ catalyst $(500 \mathrm{mg})$, and the mixture was hydrogenated for $2 \mathrm{hr}$ at $40^{\circ} \mathrm{C}$. After the same procedure as described in the preparation of 22, compound $24(350 \mathrm{mg}, 89 \%)$ was obtained as prisms, $\mathrm{mp} 187 \sim 188^{\circ} \mathrm{C},[\alpha]_{\mathrm{D}}^{15}-10.5^{\circ}(c=0.3$, $\mathrm{MeOH} ; 24 \mathrm{hr}) ; v_{\max }^{\mathrm{Nujol}} \mathrm{cm}^{-1}: 3360(\mathrm{OH}), 3240(\mathrm{NH})$, and 1640, 1550 and 1510 (amide). Anal. Found: C, 48.16; H, 6.90; N, 15.15. Calcd. for $\mathrm{C}_{11} \mathrm{H}_{19} \mathrm{~N}_{3} \mathrm{O}_{5}: \mathrm{C}, 48.34 ; \mathrm{H}, 7.01$; $\mathrm{N}, 15.38 \%$.

2-Acetamido-2,3-dideoxy-5,6-O-isopropylidene- $\alpha-\mathrm{D}-$ erythro-hex-2-enofuranose (1).

(A) From 14. To a solution of $14(60 \mathrm{mg})$ in $\mathrm{MeOH}$ $(2 \mathrm{ml})$ was added Amberlite IRA-410 $\left(\mathrm{OH}^{-}\right)$ion-exchange resin $(2 \mathrm{~g})$, and the mixture was stirred for $6 \mathrm{hr}$ at room temperature. The suspension was filtered and the resin was washed with $\mathrm{MeOH}$. The filtrate and washings were combined, and evaporated to a syrup which was chromatographed on a column of silica gel $(12 \mathrm{~g})$ with $\mathrm{CHCl}_{3}$ and then 50:1 $\mathrm{CHCl}_{3}-\mathrm{MeOH}$. The latter eluate afforded a homogeneous syrup which crystallized from benzene, to give compound 1 ( $35 \mathrm{mg}, 66 \%$ ).

(B) From 15. Alkaline ion-exchange resin treatment of $15(120 \mathrm{mg})$ in $\mathrm{MeOH}$ was performed according to the procedure as described above. The title compound was obtained as crystals $(50 \mathrm{mg}, 59 \%)$.

(C) From 18. To a solution of $18(100 \mathrm{mg})$ in $\mathrm{MeOH}$ ( $3 \mathrm{ml}$ ) was added Amberlite IRA-410 (2 g), and the mixture was stirred for $24 \mathrm{hr}$ at $50^{\circ} \mathrm{C}$. After the same treatment as already described, the title compound $(40 \mathrm{mg}, 43 \%)$ was obtained, $\mathrm{mp} 152^{\circ} \mathrm{C},[\alpha]_{\mathrm{D}}^{25}-21^{\circ}(2 \mathrm{~min}) \rightarrow-5^{\circ}(5 \mathrm{hr}) \rightarrow$ $+0.7^{\circ}(c=1.0, \mathrm{MeOH} ; 17 \mathrm{hr}),[\alpha]_{\mathrm{D}}^{25}-35^{\circ}(2 \mathrm{~min}) \rightarrow-33^{\circ}$ $\left(c=0.5, \mathrm{CHCl}_{3} ; 2 \mathrm{hr}\right),[\alpha]_{\mathrm{D}}^{25}-58^{\circ}(2 \mathrm{~min}) \rightarrow-57^{\circ}(c=0.5$, DMSO; 2 hr); lit. ${ }^{9)} \mathrm{mp} 156 \sim 158^{\circ} \mathrm{C},[\alpha]_{\mathrm{D}}^{20}-3.7^{\circ}(7 \mathrm{~min}) \rightarrow$ $+11.3^{\circ}\left(c=0.99,4: 1 \mathrm{MeOH}-\mathrm{H}_{2} \mathrm{O} ; 20 \mathrm{hr}\right)$.

2,5-Diacetamido-2,3,5-trideoxy-D-glycero-pent-2-enofuranose (25).

(A) From 22. To a solution of $22(300 \mathrm{mg})$ in $\mathrm{MeOH}$ $(15 \mathrm{ml})$ was added Amberlite IRA-410 (3g), and the mixture was stirred for $14 \mathrm{hr}$ at room temperature. The resin was filtered and washed with $\mathrm{MeOH}$. The filtrate and washings were combined and evaporated below $40^{\circ} \mathrm{C}$. The syrupy residue was chromatographed on a column of alumina gel $(10 \mathrm{~g})$ with $20: 1 \mathrm{CHCl}_{3}-\mathrm{MeOH}$ to afford a syrup $(230 \mathrm{mg})$, which was crystallized from acetone-ether to give compound $25(200 \mathrm{mg}, 67 \%), \mathrm{mp} 105 \sim 115^{\circ} \mathrm{C}$ (dec.), $[\alpha]_{\mathrm{D}}^{28}-5^{\circ}(c=0.2, \mathrm{MeOH} ; 24 \mathrm{hr}) ; v_{\max }^{\text {Nujol }} \mathrm{cm}^{-1}: 3480$ $3240(\mathrm{OH}$ and $\mathrm{NH}), 1680(\mathrm{C}=\mathrm{C})$, and 1610 and 1570 (amide); NMR $\delta\left(90 \mathrm{MHz}, \mathrm{DMSO}-d_{6}\right): 1.80$ and $1.94(6 \mathrm{H}$, $2 \mathrm{~s}, 2 \mathrm{AcN}), 3.12\left(2 \mathrm{H}, \mathrm{m}, J_{4,5}=6.8, J_{4,5^{\prime}}=5.8, J_{5, \mathrm{NH}}=12.8\right.$, $J_{5^{\prime}, \mathrm{NH}}=11.8 \mathrm{~Hz}, \mathrm{H}-5$ and $\left.\mathrm{H}-5^{\prime}\right), 6.42$ and $6.58(1 \mathrm{H}, 2 \mathrm{~d}$, $\mathrm{OH}), 7.75(1 \mathrm{H}, \mathrm{m}, \mathrm{NH}$ at $\mathrm{C}-5)$, and $9.64(1 \mathrm{H}, \mathrm{s}, \mathrm{NH}$ at $\mathrm{C}-$ 2). Other NMR data are given in Table I. Anal. Found: C, 46.58; $\mathrm{H}, 6.90 ; \mathrm{N}, 11.82$. Calcd.for $\mathrm{C}_{9} \mathrm{H}_{14} \mathrm{~N}_{2} \mathrm{O}_{4} \cdot \mathrm{H}_{2} \mathrm{O}: \mathrm{C}$, $46.54 ; \mathrm{H}, 6.94 ; \mathrm{N}, 12.06 \%$.

(B) From 23. To a solution of $23(150 \mathrm{mg})$ in $\mathrm{MeOH}$ $(3 \mathrm{ml})$ was added Amberlite IRA-410 (1.5 g), and the mixture was stirred for $20 \mathrm{hr}$ at $40^{\circ} \mathrm{C}$. After the same treatment as described above, compound 25 (65 mg, 43\%) was obtained as crystals.

2,5-Diacetamido-2,5-dideoxy-D-xylopyranose (26). To a solution of $22(300 \mathrm{mg})$ in $\mathrm{MeOH}(15 \mathrm{ml})$ was added Amberlite IRA-410 (3g), and the mixture was stirred at room temperature. After $20 \mathrm{~min}$, the ratio of the product to the starting material reached $\sim 1: 1$ on TLC, but compound 25 had not yet been detected. The resin was filtered off and washed with $\mathrm{MeOH}$. The filtrate and washings were combined, and evaporated. The solid mass thus obtained was crystallized from $\mathrm{MeOH}$ to give compound 26 as needles (70 mg, 24\%), mp $190 \sim 192^{\circ} \mathrm{C}$ (dec.), $[\alpha]_{\mathrm{D}}^{20}+17^{\circ}(c=0.38, \mathrm{MeOH} ; 24 \mathrm{hr}) ; v_{\max }^{\mathrm{Nujol}} \mathrm{cm}^{-1}: 3400$, 3300 and 3250 ( $\mathrm{OH}$ and $\mathrm{NH}$ ), and 1610 and 1540 (amide). Anal. Found: C, 46.31; H, 6.84; N, 11.96. Calcd. for $\mathrm{C}_{9} \mathrm{H}_{16} \mathrm{~N}_{2} \mathrm{O}_{5}: \mathrm{C}, 46.54 ; \mathrm{H}, 6.94 ; \mathrm{N}, 12.06 \%$.

2,5-Diacetamido-1,3,4-tri-O-acetyl-2,5-dideoxy- $\alpha$-Dxylopyranose (27). Compound $26(40 \mathrm{mg})$ was acetylated with acetic anhydride $(0.5 \mathrm{ml})$ in pyridine $(5 \mathrm{ml})$ overnight at $0^{\circ} \mathrm{C}$. After the usual treatment, the product was obtained as prisms $(50 \mathrm{mg}, 81 \%), \mathrm{mp} 178 \sim 179^{\circ} \mathrm{C},[\alpha]_{\mathrm{D}}^{20}+30^{\circ}$ $\left(c=0.25, \mathrm{CHCl}_{3}\right) ; v_{\max }^{\mathrm{Nujol}} \mathrm{cm}^{-1}: 3250(\mathrm{NH}), 1750$ and 1220 (ester), and 1650 and 1550 (amide); NMR $\delta(90 \mathrm{MHz}$ ): $1.95,2.06,2.07,2.16,2.29(15 \mathrm{H}, 5 \mathrm{~s}, 2 \mathrm{AcN}$ and $3 \mathrm{AcO})$, $2.78\left(1 \mathrm{H}, \mathrm{t}, J_{\mathrm{gem}}=J_{4,5 \mathrm{a}}=10.2 \mathrm{~Hz}, \mathrm{H}-5 \mathrm{a}\right), 4.28(1 \mathrm{H}, \mathrm{m}$, $\mathrm{H}-2), 4.75(1 \mathrm{H}, \mathrm{m}, \mathrm{H}-5 \mathrm{e}), 4.94\left(1 \mathrm{H}, \mathrm{m}, J_{3,4}=9.1\right.$, $\left.J_{4,5 \mathrm{a}}=10.2, J_{4,5 \mathrm{e}}=5.7 \mathrm{~Hz}, \mathrm{H}-4\right), 5.27\left(1 \mathrm{H}, \mathrm{dd}, J_{2,3}=10.7\right.$, $\left.J_{3,4}=9.1 \mathrm{~Hz}, \mathrm{H}-3\right), 6.04\left(1 \mathrm{H}, \mathrm{d}, J_{2, \mathrm{NH}}=8.0 \mathrm{~Hz}, \mathrm{NH}\right)$ and $6.52\left(1 \mathrm{H}, \mathrm{d}, J_{1,2}=3.8 \mathrm{~Hz}, \mathrm{H}-1\right)$. Anal. Found: C, 50.16; H, 6.13; N, 7.80. Calcd. for $\mathrm{C}_{15} \mathrm{H}_{22} \mathrm{~N}_{2} \mathrm{O}_{8}: \mathrm{C}$, $50.27 ; \mathrm{H}, 6.19 ; \mathrm{N}, 7.82 \%$.

\section{2,3,5-Triacetamido-2,3,5-trideoxy-D-ribopyranose (28).}

To a solution of $24(200 \mathrm{mg})$ in $\mathrm{MeOH}(5 \mathrm{ml})$ was added Amberlite IRA-410 (2g), and the mixture was stirred overnight at room temperature. The starting material was 
no longer detectable on TLC. The resin was removed by filtration and the filtrate was evaporated to afford a crystalline product; it was recrystallized from $\mathrm{EtOH}$ to give needles $(120 \mathrm{mg}, 60 \%), \operatorname{mp~} 251^{\circ} \mathrm{C},[\alpha]_{\mathrm{D}}^{20}+36.5^{\circ}(c=$ $0.5, \mathrm{MeOH} ; 24 \mathrm{hr}) ; v_{\max }^{\mathrm{Nujol}} \mathrm{cm}^{-1}: 3350-3270(\mathrm{OH}, \mathrm{NH})$, and 1640 and 1540 (amide). Anal. Found: C, 48.18; H, 6.93; N, 14.98. Calcd. for $\mathrm{C}_{11} \mathrm{H}_{19} \mathrm{~N}_{3} \mathrm{O}_{5}: \mathrm{C}, 48.34 ; \mathrm{H}, 7.01 ; \mathrm{N}$, $15.38 \%$.

2,3,5-Triacetamido-1,4-di-O-acetyl-2,3,5-trideoxy-Dribopyranose (29). Compound $28(50 \mathrm{mg})$ was acetylated with acetic anhydride $(1 \mathrm{ml})$ in pyridine $(5 \mathrm{ml})$ overnight at $0^{\circ} \mathrm{C}$. Compound 29 was obtained as an amorphous mass (65 mg, quantitative); $v_{\max }^{\text {Nujol }} \mathrm{cm}^{-1}: 3260$ (NH); 1750 $(\mathrm{C}=\mathrm{O})$, and 1650 and 1540 (amide); NMR $\delta(90 \mathrm{MHz}$, $\left.\mathrm{CD}_{3} \mathrm{OD}\right): 1.97,1.98,2.10$ and $2.12(15 \mathrm{H}, 4 \mathrm{~s}, 3 \mathrm{AcN}$ and 2AcO), $6.00\left(J_{1,2}=2.2 \mathrm{~Hz}, \mathrm{H}-1\right.$ of $\alpha$-anomer), and 6.16 (d, $J_{1,2}=4.3 \mathrm{~Hz}, \mathrm{H}$-1 of $\beta$-anomer). Anal. Found: C, 50.29; $\mathrm{H}$, 6.28; N, 11.47. Calcd. for $\mathrm{C}_{15} \mathrm{H}_{23} \mathrm{~N}_{3} \mathrm{O}_{7}: \mathrm{C}, 50.42 ; \mathrm{H}, 6.49$; $\mathrm{N}, 11.76 \%$.

Acknowledgments. We thank Professor Ichiro Azuma for his encouragement and Miss Mutsuko Araki for typing the manuscript.

\section{REFERENCES}

1) R. Kuhn and G. Krüger, Chem. Ber., 89, 1473 (1956).
2) A. Hasegawa and H. G. Fletcher, Jr., Carbohydr. Res., 29, 223 (1973).

3) A. Hasegawa, T. Sakurai and N. Hasegawa, Carbohydr. Res., 45, 19 (1975).

4) A. Hasegawa, N. Aritake and M. Kiso, Carbohydr. Res., 52, 137 (1976).

5) A. Hasegawa and M. Kiso, Carbohydr. Res., 63, 91 (1978).

6) H. Ohrui, N. Sueda and S. Emoto, Agric. Biol. Chem., 42, 865 (1978).

7) A. Hasegawa, H. Okumura, K. Nishibori, Y. Kaneda, M. Kiso and I. Azuma, Carbohydr. Res., 97, 337 (1981).

8) A. Hasegawa and M. Kiso, Carbohydr. Res., 74, 341 (1979).

9) J-M. Beau, P. Rollin and P. Sinaÿ, Carbohydr. Res., 53, 187 (1977).

10) A. Hasegawa, N. Aritake and M. Kiso, Carbohydr. Res., 81, 23 (1980).

11) A. Hasegawa, E. Tanahashi and M. Kiso, Carbohydr. Res., 79, 255 (1980).

12) P. L. Durette and D. Horton, J. Org. Chem., 36, 2658 (1971).

13) H. Paulsen, Angew. Chem., 78, 501 (1966).

14) R. V. Lemieux, K. A. Watanabe and A. A. Pavia, Can. J. Chem., 47, 4413 (1969).

15) R. J. Ferrier and J. R. Hurford, Carbohydr. Res., 38, 125 (1974). 